\title{
Reflections of Turkish Culture on Kosovo Education System: A Study on Hidden Curriculum*
}

\author{
Hasan Hüseyin Şahan ${ }^{1, *}$, Nihat Uyangör ${ }^{1}$, Serdan Kervan ${ }^{2}$ \\ ${ }^{1}$ Department of Educational Sciences, Necatibey Faculty of Education, Balıkesir University, Turkey \\ ${ }^{2}$ Department of Primary Education, Education Faculty, University of Prizren, Prizren, Kosovo
}

Copyright $(2019$ by authors, all rights reserved. Authors agree that this article remains permanently open access under the terms of the Creative Commons Attribution License 4.0 International License

\begin{abstract}
This is a qualitative study analyzing the effect of Turkish culture on Kosovo education system within the framework of hidden curriculum. In terms of methodology, it is a case study collecting data by means of interviews, observations, and document analysis. A combination of descriptive and content analysis techniques was used in data analysis. The research showed that Kosovo Turks possess the identity consciousness necessary to conserve their culture. The language, culture, and identity, which are the key stones of culture, are present in the young generation, as well as in the middle aged and the elderly. The study revealed various hidden curriculum elements showing the effect of Turkish culture on Kosovo education system. The main finding of the study is that cultural transmission takes place in hidden curriculum through teachers, in-class and extensive activities, and course books. The study concluded that Kosovo Turks, who have suffered intense pressure from different ethnic groups in the educational, social, and political spheres so far, now show serious commitment to their culture. This is indicative of that Turkish culture will be transferred to the younger generations in the future.
\end{abstract}

Keywords Hidden Curriculum, Culture Transmission, Kosovo Education System

\section{Introduction}

As a result of the increasing migratory movements and globalization in the world, certain social structures and cultural diversity have emerged in many regions, especially in western countries. Still, just like in the past, societies maintain and will maintain their existence by preserving and fostering their cultural heritage, and by transferring it to the coming generations.

Culture is the reflection of emotions and ideas on life in every stage of life [1]. Indeed, all that have been created and produced by the human beings (customs, art, knowledge and education, accommodation types, ways of production and consumption, governance, nutrition and health, belief systems and religion) form the culture [2]. An analysis of these constituents of culture shows that, conceptually, culture is a universal value, and practically, it is a social value. By its inherent characteristics, this concept flourishes in the values of its local region and is specific to societies [3]. Culture, which refers to the life style that has formed as a result of the perceptions, interests, and experiences a nation has developed and to the materials and spiritual values that they have accumulated over centuries, has been transferred to future generations throughout history for the continuation and development of societies. Culture, which is the sum of life, material and spiritual values formed by the perceptions, interests, attitudes and experiences created by a nation over the centuries, is transferred to generations throughout history for the continuation and development of the society [1].

Education is one of the most important institutions for the protection and transmission of culture [4]. Cultural transmission takes place in two ways in educational institutions: through formal curricula designed according to political, economic, and societal expectations, and through hidden curricula involving interactions, experiences, and messages beyond formal features. Through hidden curriculum, students gain knowledge, skills, feelings, attitudes, opinions, and values, other than those stated in the formal curriculum [5]. Indeed, it has a far more effective nature than the formal education in the process of culture transmission.

A large portion of cultural transmission within hidden curriculum is actualized by means of teachers, activities carried out in and outside of class, and course books. According to [5], as teachers implement the formal curriculum, they intentionally or unintentionally reflect their own views, feelings, opinions, and perspectives on the teaching process through in-class or extensive activities. Indeed, the impact of these teachers' activities on students is often larger than that of the formal education. Language teaching course books, in particular, have a considerable role in gaining the students the outcomes of the hidden 
curriculum [6].

The abovementioned characteristics of hidden curriculum are gaining wide significance for culture transmission in multicultural societies, which are rapidly increasing for various reasons, as they help the protection of their own cultures and the development of tolerance towards other cultures. This understanding is especially important in Kosovo because different ethnic, religious, and cultural groups, which have gone through the imperial and colonial times, have been living together here, and at the same time, each subculture pursues to exist and develop within itself [7]. Within this multicultural structure in Kosovo, Turks endeavor to sustain and develop their deep-rooted history and culture through education.

An analysis of the related literature shows that educational research about Kosovo has commonly focused on Kosovo's education system [8], multicultural education [9:10], and the analysis of formal curriculum implemented at Kosovo education system [11:12]; it seems that no research has been conducted on the hidden curriculum in Kosovo education system. In addition, despite the strong cultural bonds between Turkey and Kosovo, no research exists on the interaction between their educational systems, which adds to the significance of the study. Hidden curriculum applications are important means of culture transmission; accordingly, an analysis of the effect of Turkish culture on Kosovo's education system with particular emphasis on hidden curriculum was thought to be critical for the preservation and development of Turkish culture in Kosovo, and for its transmission to future generations.

Thus, the present study intends to analyze the effects of the Turkish culture on the Kosovo education system within the scope of hidden curriculum. The study seeks answers to the following research questions:

1. What is teachers' perception of the reflections of Turkish culture on Kosovo education system?

2. What is the role of the curricular and extracurricular activities as regards the reflection of Turkish culture on Kosovo education system?

3. What is the role of textbooks in Turkish in hidden curriculum as regards the reflections of Turkish culture on Kosovo education system?

\section{Materials and Methods}

\subsection{Research Design}

This is a qualitative study analyzing the reflections of Turkish culture on the Kosovo education system within the scope of hidden curriculum. An analysis of the related literature underscored the necessity of using qualitative research methods in studies focusing on hidden curriculum [13:14:5]. To better serve the aim of the study, case study, which is a qualitative research method, was adopted.

\subsection{Study Group}

The participants of the study were selected through homogeneous sampling, which is a type of purposive sampling. Accordingly, 14 Turkish teachers working at Turkish schools at Kosovo and teaching classes of Turkish students were interviewed. Furthermore, to unravel the reflections of Turkish culture on Kosovo education system, eight observations were made in different time periods both in and outside the classroom. The observations were carried out at Kosovo schools offering education in Turkish and in classrooms of Turkish teachers. Moreover, course books in Turkish that are used at 1st, 2nd, 3rd, 4th, and 5th grades of primary schools were analyzed to identify the effect of Turkish culture on the education system in Kosovo.

\subsection{Data Collection Instruments}

A variety of data collection tools were used together to ensure richness and triangulation of data [15]. To this end, first, interview forms were used to elicit teachers' views. The potential items were initially developed based on a review of literature. A tentative version of the interview form was subjected to expert view with particular emphasis on its content and validity. Upon its revision based on the expert opinion, it was piloted on two teachers who were working in Kosovo and who were not included in the study group to test the clarity of interview questions, and then it was finalized.

A semi-structured interview form was developed by the researchers to shed light on in-class and out-of-class activities of the hidden curriculum as regards the effect of Turkish culture on Kosovo education system. Prior to the development of this tool, a thorough literature review was made to discover the possible dimensions pertaining to the purpose of the study. After this extensive literature review, a draft form was prepared showing which dimensions were to be observed. It was then evaluated by experts from the field and finalized after the necessary revisions.

An analysis of course books in Turkish was conducted to discover their role in hidden curriculum as regards the effect of Turkish culture on Kosovo education system. The document analysis method was used for this purpose as it is widely used in linguistic studies involving the inspection of written materials [15].

\subsection{Data Collection and Analysis}

To identify the reflections of Turkish culture on the Kosovo education system, face-to-face interviews were conducted with 14 teachers in the study group. To this end, first, schools and classes providing education in Turkish were identified, and necessary permissions were obtained from the school administrators. Then, observations in and out of class were conducted in eight different time periods. At the beginning of every interview, the interviewer 
explicitly stated the purpose of the study and highlighted the importance of clarity in expression of opinions for the quality of the research. The participants' consent was taken about tape-recording the interviews, which lasted 25 minutes in average. The observations were made by the researchers, and vivid and detailed observation notes were taken during the observations. In addition, when specific features that relate to the Turkish culture were observed in and out of the school environment, they were photographed and archived. Finally, course books in Turkish that are used in 1st, 2nd, 3rd, 4th, and 5th grades were subjected to document analysis.

Descriptive analysis and content analysis methods were employed in the data analysis stage. They were used in conjunction with each other because some sub-categories and concepts in the conceptual framework of hidden curriculum required the use of descriptive analysis, and some content analysis. The data analysis process involved data organization, i.e., subjecting the database to precoding, coding the themes and grouping them, and presenting and interpreting the emerging data [16].

The analysis process of data collected from interviews, observations, and document analyses involved coding of the data first. Then, subthemes and main themes were formed from the recurring codes. The data collected were visually represented and supported by concrete evidence. The quotations that match with the findings were coded as $\mathrm{T} 1$, T2, etc. for ethical reasons. As regards the presentation of observation data, codes that signify the order of observations (e.g., O1, O2) were used. The specific extracts from the document analysis data was presented by using class and page numbers (e.g., 1-70, 4-104).

\subsection{Validity and Reliability}

To ensure internal validity of the study, presentation of data was often supported by direct quotations. Moreover, the data collected by various methods was handled and discussed in a holistic fashion. The main data source in the study is teachers, and the data collection instruments are interview, observation, and document analysis. The data collected from different sources and by means of different tools were triangulated and presented in relation with each other. In addition, to increase the credibility of the study, consistency was pursued at data collection, data analysis, and interpretation phases. To assure external validity, detailed explanation concerning how the data was collected and analyzed was provided. Detailed instructions necessary for the replication of the study were given in the research report.

To assure internal reliability, triangulation of data, in terms of data source and method, was considered essential. The presentation of the results was parallel to the research questions. To confirm the clarity of the research questions, they were expressed in the same way. To eliminate issues about reliability, Miles and Huberman's (1994) reliability formula denoted as follows was used: $\mathrm{P}$ (concordance coefficient \%) $=[\mathrm{Na}$ (Coder agreement) $/ \mathrm{Na}$ (Coder agreement) $+\mathrm{Nd}$ (Coder disagreement)] X 100. The reliability coefficient was calculated as $9 \%$. Procedures performed to achieve external reliability in the research design and research process, data collection and analysis, i.e., all that were performed up to the findings and conclusions, were described in detail. Data loss was prevented as the interviews were tape-recorded. Observation forms were filled right after the particular observation. The record of data obtained from document analysis of course books was kept through numbers attached to books and pages. Each and every data was stored.

\section{Results}

Table 1 presents teachers' views on the reflection of Turkish culture on the Kosovo education system.

Table 1. Teachers' Views on the Reflection of Turkish Culture on the Kosovo Education System

\begin{tabular}{|c|c|c|}
\hline Main Theme & Sub-themes & Codes \\
\hline \multirow{2}{*}{$\begin{array}{l}\text { General } \\
\text { Evaluation }\end{array}$} & Formal & $\begin{array}{l}\text { Constitution } \\
\text { Framework of the program } \\
\text { Objectives } \\
\text { Curricular Activities }\end{array}$ \\
\hline & Hidden & $\begin{array}{l}\text { Bayrams and Celebrations } \\
\text { Turkish customs and } \\
\text { traditions } \\
\text { Activities }\end{array}$ \\
\hline \multirow{2}{*}{ Activities } & In-class & $\begin{array}{l}\text { Ceremonies } \\
\text { Shows } \\
\text { Decoration } \\
\text { Competitions }\end{array}$ \\
\hline & Outside-of-class & $\begin{array}{l}\text { Ceremonies } \\
\text { Trips } \\
\text { Shows } \\
\text { Exhibitions }\end{array}$ \\
\hline \multirow[t]{2}{*}{$\begin{array}{l}\text { Teacher } \\
\text { Behaviors }\end{array}$} & In-class & $\begin{array}{l}\text { Being a role model } \\
\text { Using supplementary } \\
\text { materials in Turkish } \\
\text { Setting rules } \\
\text { Promotion (Turkish poets } \\
\text { and authors) }\end{array}$ \\
\hline & Outside-of-class & $\begin{array}{l}\text { Being a role model } \\
\text { Organizing activities (trips, } \\
\text { ceremonies, etc.) }\end{array}$ \\
\hline \multirow[b]{2}{*}{ Course books } & Visual & $\begin{array}{l}\text { Flag } \\
\text { Turkish soldiers } \\
\text { Turkish costumes } \\
\text { Pictures and photographs }\end{array}$ \\
\hline & Textual & $\begin{array}{l}\text { Poems } \\
\text { Stories and Tales } \\
\text { Proverbs } \\
\text { Epic stories and legends } \\
\text { Jokes } \\
\text { Reading Texts }\end{array}$ \\
\hline
\end{tabular}

As can be seen in Table 1, comments of the participants on the reflections of Turkish culture on the education 
system in Kosovo were categorized in the four main themes of general evaluation, activities, teacher behaviors, course books, and in eight sub-themes.

Teacher comments about the reflection of Turkish culture on the education system in Kosovo were grouped into two: formal and hidden. Constitution, program framework, objectives, and curricular activities emerged from the teacher comments and were categorized as the sub-themes of formal curriculum. Bayrams and ceremonies, Turkish customs and traditions, informal activities were categorized as the sub-themes of hidden curriculum. Some teacher comments confirming these findings are as follows:

(T5) ... the rights of minorities are protected by the Constitution of Kosovo. Indications of Turkish culture can be seen in the framework of formal education at schools. They are most obvious in the learning outcomes and activities of the Turkish class ...

(T3) ...Hidden curriculum is somewhat the most effective program that maintains the Turkish culture since the Turkish culture can be best transferred through activities such as bayrams and festivals, and other activities geared towards gaining customs and traditions ...

As can be seen in the Table, the participants' responses about the reflections of Turkish culture on the Kosovo education system were grouped into two: in-class and out-of-class. Celebrations, performances, decorations, and class competitions were considered within the scope of in-class activities. On the other hand, out-of-class activities involved celebrations, excursions, shows, and exhibitions, which were regarded as cultural reflections within the scope of hidden curriculum. Some related participant remarks are as follows:

(T4) ...As regards in-class activities, we organize class competitions involving elements of Turkish culture, e.g. Students' Pledge Recitation Competition, decorating our classroom on special days and weeks indicated on the timeline, and holding activities on important days that are celebrated in Turkey ...

(T8) ...As regards out-of-class activities, it is important to wear Turkish folk dance outfits and read Turkish poems during visits to official authorities or excursions. ...

The teacher behaviors were also analyzed, and codes pertaining to being a role-model, using supplementary materials in Turkish, setting rules, informative activities (e.g., Turkish poets and writers) were grouped under the sub-theme of in-class, and codes about being a role-model, organizing activities (e.g., trips, ceremonies) were grouped under the subtheme of out-of-class. Some quotations that verify these findings are as follows:

(T12) ...For example, we determine the rules on the first days of school according to Turkish manners and customs. Rules about standing up when an elderly enters the classroom, saying 'welcome', taking turns before speaking, kissing the hands of elderly, and being respectful are of priority. I first try to demonstrate them myself and act as a role-model ...

(T7) ...Unfurling and kissing the Turkish flag during ceremonies while poems are being recited are a behavior student have adopted as a result of teachers' modelling ....

In Table 2, the participants' views on course books, or more specifically, on cultural reflections on the books within the scope of hidden curriculum were classified into two: visual and textual. Flags, Turkish soldier, Turkish costumes, pictures and photographs were grouped under the subtheme of visuals, while poems, stories and tales, proverbs, epic stories and legends, jokes and reading texts involving elements of Turkish culture were grouped under the subtheme of textual. Some sample quotations of teachers that have led to these findings are as follows:

(T11) ... The pictures of flags and Turkish soldiers, or other culture-specific paintings in course books have an important role for children to recognize our culture. In Kosovo, young people do not do military service, so generally Turkish soldiers are taken as a model.

(T14) ... Texts from us such as poems, stories, tales, narratives, and proverbs written by Turkish authors appear in the course books and supplementary material. In addition, examples such as Keloğlan, Turkish proverbs, Ergenekon epics, and Nasrettin Hodja jokes are significant as to culture transmission.

Table 2 presents the observation findings concerning in-class and out-of-class activities within the scope of the effect of Turkish culture in the hidden curriculum

Table 2. The reflections of Turkish culture on Kosovo Education System in the hidden curriculum

\begin{tabular}{|c|c|c|}
\hline Main themes & Sub-themes & Codes \\
\hline \multirow{3}{*}{ In-class } & Activity & $\begin{array}{l}\text { Competition } \\
\text { Decoration } \\
\text { Reading } \\
\text { Painting } \\
\text { Commemoration } \\
\text { Customs and Traditions }\end{array}$ \\
\hline & Teacher behavior & $\begin{array}{l}\text { Poem recitation } \\
\text { Rule setting } \\
\text { Badge pinning }\end{array}$ \\
\hline & Boards and corners & $\begin{array}{l}\text { Flag } \\
\text { Picture of Atatürk } \\
\text { Pictures of important days }\end{array}$ \\
\hline \multirow{3}{*}{ Out of class } & Activity & $\begin{array}{l}\text { Ceremony } \\
\text { Decoration } \\
\text { Trips } \\
\text { Exhibition }\end{array}$ \\
\hline & Teacher behavior & Poem recitation \\
\hline & Boards and corners & $\begin{array}{l}\text { Flag } \\
\text { Atatürk } \\
\text { Special days }\end{array}$ \\
\hline
\end{tabular}

As can be seen in Table 2, Turkish culture is reflected by means of hidden curriculum elements such as the classroom activities on the curriculum mainstream (competitions, decorations, readings, paintings, 
commemorations, customs and traditions), teacher behaviors (having students read poems, setting rules and badge-pinning), and bulletin boards and corners (flag, pictures of Atatürk and special days). It is also reflected through hidden curriculum elements that exist out of class: activities (ceremonies, decoration, trips and exhibitions), teacher behaviors (reading poems), bulletin boards and corners (flag, pictures of Atatürk and special days). Some related observation notes are as follows:

(O1) In social studies class, the teacher held Mehmet Akif Ersoy Commemoration Day. The classroom was decorated; the teacher told about Mehmet Akif Ersoy's life story, as well as holding a national anthem recitation competition. The students took turns to recite the anthem and put on the Mehmet Akif Ersoy badge during the competition. The best three were awarded a Turkish flag.

(O3) In the Turkish class, the teacher first read out the text "The Granny and the Grandchild" herself, and then had the students read it out. She asked follow-up questions about the text. The students answered them. Then, they dramatized the text. The student who played the role of the grandchild kissed the hand of the student who played the granny.

(O5) Atatürk's corner was prepared in the class on 10th of November. Turkish flags, pictures of Atatürk, photographs and poems depicting Atatürk's life were hung on this corner.

(O6) Upon entering the Turkish class, the teacher said, "Let's first set the classroom rules". The teacher told the students that they have to stand up when an elderly enters the room as a sign of respect and say "welcome". The teacher also reminded that they have to stand up when the guest is leaving, highlighting that these are our traditions. The students approved this explanation.

(O2) The school was decorated on 23th of April. A ceremony was held for the bayram in the school yard. The students recited poems and sang anthems about 23rd of April, and they prepared a special corner in the classroom showing many pictures and visuals they themselves had prepared.

(O4) 18th March Çanakkale Martyrs Commemoration Ceremony was organized at school. The students drew pictures of soldiers and painted them. The teachers and students prepared a Çanakkale board together and hang them on the wall of the corridor. They read poems about Çanakkale and sang the Çanakkale anthem.

(O6) "First Day at School" organization was held, during which Turkish and Kosovo Flags were hung on the walls side by side.

(O7) A trip to the Tomb of Sultan I Murad Hüdavendigar was arranged. During the trip, the students were given historical information, and they were told about the Battle of Kosovo. The teachers and students prayed together at the tomb.

For the reflections of Turkish culture on the education system in Kosovo, course books of Turkish were also analyzed, and the findings are displayed in Table 3.

Table 3. The reflections of Turkish culture on Kosovo Education System - Document analysis findings on Turkish course books

\begin{tabular}{|c|c|c|}
\hline $\begin{array}{l}\text { Main } \\
\text { theme }\end{array}$ & Sub-themes & Codes \\
\hline \multirow[t]{2}{*}{ Visual } & Picture & $\begin{array}{l}\text { Nasrettin Hodja } \\
\text { Flag of Turkey } \\
\text { Keloğlan } \\
\text { Bayrams } \\
\text { Karagöz-Hacivat } \\
\text { Important days }\end{array}$ \\
\hline & Photograph & $\begin{array}{l}\text { Atatürk } \\
\text { Turkish folk dance } \\
\text { Whirling performance }\end{array}$ \\
\hline \multirow{5}{*}{ Text } & Poem & $\begin{array}{l}\text { Bayrams } \\
\text { Atatürk }\end{array}$ \\
\hline & $\begin{array}{l}\text { Informative Writing } \\
\text {-Anecdote }\end{array}$ & $\begin{array}{l}\text { Bayrams } \\
\text { Important days } \\
\text { Nasrettin Hodja } \\
\text { Tolerance } \\
\text { Atatürk } \\
\end{array}$ \\
\hline & $\begin{array}{l}\text { Narrative, Tale, } \\
\text { Story }\end{array}$ & $\begin{array}{l}\text { Keloğlan Karagöz-Hacivat } \\
\text { (Shadow puppetry) }\end{array}$ \\
\hline & Proverb & Turkish proverbs \\
\hline & Joke & Nasrettin Hodja \\
\hline
\end{tabular}

As can be seen in Table 3, data obtained from the analysis of Turkish course books were categorized into two main themes, and seven sub-themes. Overall, it can be concluded that the course books include similar amounts of visuals and texts that reflect the Turkish culture.

Within the visual dimension of hidden curriculum, elements reflecting the Turkish culture can be found: Nasrettin Hodja (1-70, 4-104), Turkish flag (1-90), Keloğlan (1-132, 5-109), bayrams (1-137, 4-135, 4-175), Karagöz-Hacivat (2-16), pictures of important days (3-59), Atatürk (2-39, 5-63), Turkish folk dances (3-44, 5-138)and whirling performances (1-155). The textual dimension involved poems about bayrams (1-137, 2-243, 3-18, 3-44, 4-135) and Atatürk (2-39, 4-46), and informative texts and anecdotes on bayrams (2-23, 4-175), important days (3-52), Nasrettin Hodja (5-97), tolerance (1-155) and Atatürk (5-63). Other hidden curriculum elements that emerged in book analyses are tales and stories such as Keloğlan (1-132), Karagöz-Hacivat (2-16), and Turkish proverbs (2-108, 5-167) and Nasrettin Hodja jokes (2-86, $4104,5-$

\section{Discussion and Conclusions}

Any It is essential to transfer the Turkish culture to preserve and develop it in Kosovo, enable the young generations to internalize it, generate resistance against cultural imperialism, prevent cultural erosion, and nourish national consciousness in the new generations, which will protect us from internal and external threats to our national unity.

The findings of the research demonstrate that Kosovo 
Turks have the cultural identity awareness needed to sustain their culture. It is observed that language, culture, and identity awareness, which are the main constituents of culture, exist in both younger generations, and middle and older generations. This signals that Turkish language and culture will be transferred to young generations. Kosovo Turks have been oppressed by members of different ethnic groups in educational, social, and political spheres, which is why they are seriously committed to their language and culture today.

Overall, the research revealed that there are many elements of hidden curriculum involving reflections of Turkish culture in the Kosovo education system. It also showed that cultural transmission is achieved by means of teachers, extra-curricular activities, and course books. It was found that the teachers carry out various activities in and out of the class to display the Turkish culture, as well as performing cultural transmission through their own acts and behaviors. Indeed, most of the in-class and extensive culture oriented activities introducing the Turkish culture were found to be held by teachers. These results derived from the interviews and observations seem to be in agreement with each other.

Course books are one of the most critical agents of hidden curriculum [6]. According to Kalfa [17], in the Turkish language teaching, elements involving the Turkish culture should be transmitted in class environment and through course materials. The present study revealed that Turkish course books transmit the Turkish culture by means of both visuals and written texts. The data collected from interviews and that from document analysis are in concordance with each other. Melanlıoğlu [18], who associates language teaching with culture teaching, conducted a research, which yielded similar results: culture transmission should performed systematically and in a planned way in Turkish courses. Tüm and Sarkmaz [19] assert that effective materials selected according to students' interests, needs, and competences are of great importance in Turkish language teaching. Lohaj [20] analyzed English language course books used in the Kosovo education system and concluded that there are no cultural elements of Albanians and there are few cultural aspects of Serbs in the English language textbooks. Lewicka and Waszau [21]) analyzed course books in terms of the extent to which they entail elements of cultural and regional knowledge and found that the course books have aspects that form the students' socio-cultural competence.

In the light of these findings, the Turkish community and the Turkish Ministry of National Education have important responsibilities in protecting the Turkish culture in Kosovo and showing that Turks living there are not alone. Kosovo Turks should be financially and morally supported. Activities should be organized and projects should be conducted towards the protection of Kosovo Turks' loyalty to their culture and transmission of their national consciousness to future generations. To help the Turkish students in Kosovo to get to know and internalize their culture, periodical trips to schools in Turkey should be organized. In the same way, trips from Turkey to Kosovo schools can be arranged to achieve cultural transmission. Furthermore, the experts in this field should be encouraged to write Turkish textbooks showing the Turkish culture in accordance with the education program in Kosovo, and policies should be adopted relieving the writers of any obstacle encountered in the book writing process. The artistic features of Kosovo Turks should be enhanced; competitions for poem, novel, story writing in Turkish should be organized more frequently. The fact that Turkish is the language of science, art, and literature should be emphasized at all times, and greater place should be given to elements reflecting the Turkish culture on the level of both formal and hidden curriculum.

\section{REFERENCES}

[1] Göçer, Ali (2012). Dil-Kültür İlişkisi ve Etkileşimi Üzerine, Türk Dili, 729, 50-57.

[2] Güvenç, B. (1994). İnsan ve Kültür (Altıncı Baskı). İstanbul: Remzi Kitabevi.

[3] Başbay, A. ve Bektaş, Y. (2009). Çokkültürlülük Bağlamında Öğretim Ortamı ve Öğretmen Yeterlikleri, Eğitim ve Bilim, 34 (152), 30-43.

[4] Polat, M. ve Ceylan, Y.(2012). Alman Eğitim Sisteminde Çokkültürlülügüün İzleri: Osnabrück Üniversitesi.

[5] Yüksel, S. (2004). Örtük Program, Eğitimde Saklı Uygulamalar. Ankara: Nobel Yayın Dağıtım.

[6] Gay, G. (2014). Kültürel Değerlere Duyarlı Eğitim Teori, Araştırma ve Uygulama. (Çeviri Editörü: H. Aydın) Ankara: Anı Yayıncilik.

[7] Ünlü, İ. ve Örten, H. (2013). Öğretmen Adaylarının Çokkültürlülük ve Çokkültürlü Eğitime Yönelik Algılarının İncelenmesi, Dicle Üniversitesi Ziya Gökalp Eğitim Fakültesi Dergisi, 21 (2013) 287-302.

[8] Pupovci, D. (2002). Teacher Education in Kosova. Prishtina: University of Prishtina.

[9] Yıldırım, S. (2016). Kosova'daki Öğretmenlerin Cokkültürlü Eğitime Yönelik Bilgi, İnanç, Tutum ve Özyeterliklerinin Sınıf İçi Uygulamalarıyla İlişkisinin İncelenmesi, Yayımlanmıș Doktora Tezi. Balıkesir: Balıkesir üniversitesi Sosyal Bilimler Enstitüsü.

[10] Kervan, S. (2017). Öğretmenlerin Çokkültürlü Eğitime Yönelik Tutumları ile Epistemolojik İnançları ve Öğretim Yaklaşımları Arasındaki İlişki, Yayımlanmamış Doktora Tezi. Balıkesir: Balıkesir Üniversitesi Sosyal Bilimler Enstitüsü.

[11] Zabeli, N. (2014). Vleresimi Per Zhvillimin E Kompetencave - Sfidat Per Mesimdhenesit Kosovare. Qasja E Re Kurrikulare Sfide E Se Ardhmes- Kumtesat, Prezantimet Dhe Rekomandimet, 141-151. 
[12] Mehmeti, F. (2017). Kosova'da Altıncı Sınıf Teknoloji Dersi Öğretim Programının Değerlendirilmesi, Yayımlanmamış Doktora Tezi. Balıkesir: Balıkesir Üniversitesi Sosyal Bilimler Enstitüsü.

[13] Vallance, Elizabeth. (1980). The Hidden Curriculum and Qualitative Inquiry as States of Mind, Journal of Education, $162,1,138-151$

[14] Gordon, David. (1984). The Image Of Science. Technological Consciousness And The Hidden Curriculum, Curriculum Inquiry, 14, 4, 367-400

[15] Yıldırım, A., \& Şimşek, H. (2011). Sosyal Bilimlerde Nitel Araştırma Yöntemleri. Ankara: Seçkin Yayıncılık.

[16] Creswell, J. W. (2013). Nitel Araştırma Yöntemleri (Beş Yaklaşıma Göre Nitel Araştırma ve Araştırma Deseni). (Çev. Mesut Bütün, Selçuk Beşir Demir). Siyasal Kitabevi.

[17] Kalfa, M. (2013). Yabancilara Türkçe Öğretiminde Sözlü Kültür Unsurlarının Kullanımı, Millî Folklor, 97, 167-177.

[18] Melanlığlu, D. (2008). Kültür Aktarımı Açısından Türkçe Öğretim Programları, Eğitim ve Bilim, 33 (150), 64-73.

[19] Tüm, G. ve Sarkmaz, Ö. (2012). Yabancı Dil Türkçe Ders Kitaplarında Kültürel Ögelerin Yeri, Hacettepe Üniversitesi Eğitim Fakültesi Dergisi, 43: 448-459.

[20] Lohaj, F. (2018). English Language as A Communication Bridge in Post War Kosova, Universal Journal of Educational Research, 6 (8): 1675-1683, 2018 http://www.hrpub.org DOI: 10.13189/ujer.2018.060807.

[21] Lewicka, M. ve Waszau, A. (2017). Analysis of Textbooks for Teaching Arabic as A Foreign Language in Terms of The Cultural Curriculum, Universal Journal Of Educational Research, 5 (1), 36-44, 2017 http://www.hrpub.org DOI: 10.13189/ujer.2017.050105

* This study was supported by Balıkesir University Coordination Office of Scientific Research Projects (SRP) (project number. 2017/188). 